\title{
LA IMAGEN DEL MAESTRO ESPAÑOL, ENTRE EL MIEDO Y LA PARODIA (1876-1931)
}

\author{
The Spanish Teacher's Image, between Fear and Parody (1876-1931)
}

\author{
Ignacio Gil-Díez Usandizaga \\ Universidad de La Rioja. España \\ ignacio.gil-diez@unirioja.es | https://orcid.org/0000-0002-3497-6605
}

Fecha de recepción: 22/03/2021

Fecha de aceptación: 11/11/2021

Acceso anticipado: 19/11/2021

Resumen: Las imágenes que representan al maestro y el aula escolar han desempeñado un papel fundamental en el desarrollo de los sistemas educativos. Este artículo constituye una búsqueda del origen iconográfico de las representaciones que tuvieron una utilización dominante en España entre 1876 y 1931. Para ello se analizan estampas europeas del siglo XVI al XIX, realizadas mediante diferentes técnicas de grabado, que muestran a maestros y escolares. La continuidad de algunas de esas caracterizaciones y su actualización española, identificando al docente con el tradicional dómine, es reveladora. Su presencia, tanto en la prensa satírica destinada a los adultos como en los libros ilustrados para niños, así lo refleja. Esta imagen dedicada a la crítica y el entretenimiento tiene su contrapartida en otras escenas, también protagonizadas por maestros y escolares, que representan premios y castigos en los libros de lectura para niños en ese mismo periodo. Los factores contextuales permiten situar todo este reportorio - el desarrollo de la escolaridad y de sus protagonistas, las intenciones de los editores de los medios en las que aparecen- pero no pueden componer una interpretación suficiente sin atender al papel del ilustrador. La formación artística que este posee y los recursos que maneja en su oficio o las influencias de otros ilustradores, son aspectos concluyentes a la hora de construir el sentido final, la plena visualidad de sus imágenes estableciendo el potencial de su significado.

Palabras clave: ilustraciones; educación; maestros; premio escolar; castigo escolar. 
Abstract: Images portraying the teacher and its classroom have played an essential role in the development of educational systems. This paper constitutes a research on the iconographic origin of the representations that were mainly used in Spain between 1876 and 1931. In order to do that european cards from the 16th to the 19th centuries, made using a variety of engraving techniques, that show teachers and pupils, are analyzed. The continuity of some of these characterizations and their Spanish update, identifying the teacher with the traditional Latin dómine, it's revealing. Its presence, both in the satirical press aimed at adults and in illustrated books for children, reflects it. This image directed towards criticism and entertainment has its compensation, also starring teachers and schoolchildren, representing rewards and penalties in children's reading books in that same period of time. Contextual factors allow us to position this variety of pictures - the development of schooling and its protagonists, the editors' intentions in the media in which they appear - but they can not compose a sufficient interpretation without paying attention to the role of the illustrator. The artistic education that he posseses and the resources he manages in his profesion or the influence from other artists are conclusive aspects in order to decide the final meaning, the whole visuality of his images establishing the potencial of their meaning.

Keywords: images; education; teachers; school rewards; school punishment.

Sumario: 1. Introducción; 2. Los orígenes de la representación del maestro europeo (ss. XVI-XIX); 3. La imagen del maestro concebida como objeto de diversión y crítica; 4. La representación del maestro como herramienta del sistema escolar; 5 . Conclusiones; 6 . Referencias bibliográficas.

\section{INTRODUCCIÓN}

La importancia y el protagonismo de las manifestaciones visuales en la actualidad ha despertado un renovado interés por las del pasado. Especialistas, fundamentalmente historiadores, que antaño consideraban a la imagen como un complemento de sus trabajos, les vienen dedicando cada vez más atención. Esta focalización remueve obras y relaciones que solo ocupaban el tiempo de algunos especialistas en historia del arte (Chateau, 2017). Así, estampas, ilustraciones y otros muchos diseños que formaban parte de la historia de la cultura fundada por Jacob Burckhardt (1818-1897), reviven hoy en la corriente historiográfica que utiliza el mismo nombre (Burke, 2007).

La historia de la Educación no ha sido ajena a esta corriente, abordándose en estas últimas décadas, con una nueva mirada, las imágenes que le conciernen (Nóvoa, 2000; Castellani y Zapata, 2007; Guereña, 2007). Como en otros muchos casos, esta mirada sirve para precisar y revisar cómo se mostraron y concibieron algunos constructos visuales del proceso de enseñanza-aprendizaje (Pozo, 2006). En este sentido, el maestro, fundamentalmente representado en el pasado por personajes masculinos, es uno de los más llamativos. 
Sin querer emprender aquí, de forma exhaustiva, una revisión de todo el repertorio de imágenes que pueden servir de antecedente al período y territorio que voy a analizar, es interesante apreciar con qué finalidad se elaboraron antes del siglo XIX, en cuya segunda mitad se produce la eclosión de textos e imágenes para niños, las representaciones del maestro. Por supuesto, tras rastrear estos orígenes será necesario ver la concreción de dos grandes maneras de abordar visualmente la figura del maestro en España entre fechas tan significativas como la Restauración borbónica y el inicio de la II República.

\section{LOS ORÍGENES DE LA REPRESENTACIÓN DEL MAESTRO EUROPEO (SS. XVI-XIX)}

Muchas de las imágenes que representaron al maestro no se dirigieron, como veremos, de forma específica al ámbito escolar. Entre las que sí parecen hacerlo se encuentran varios grabados de los siglos XV y XVI. Quiero detenerme para comenzar en el muy conocido de Durero realizado en 1510 y conservado en la Biblioteca Nacional de Madrid con el nombre de El maestro de escuela (Huidobro, 2012). Esta representación (Fig. 1) acompaña a un breve texto que parece ser de carácter moralizante. La imagen es interesante por muchos motivos, uno de ellos es puramente informativo, pues indica dónde y cómo se ejerce la acción de enseñar. El maestro, ubicado en un plano visual más elevado que sus alumnos y vestido con una notable indumentaria, aparece sentado cómodamente sobre un cojín. Desde allí imparte su lección a unos jóvenes adolescentes. La escena se desarrolla al aire libre en un espacio acotado por un muro.

Otro, de naturaleza visual y, me atrevería a decir, estructural, reside en la capacidad de Durero para incorporar recursos formales que contribuyan a enfatizar contenidos e intenciones que la representación debe transmitir. La vara que el maestro porta en su mano derecha se dirige hacia sus alumnos y estos quedan bajo su mandato, el muro que cierra el espacio escolar subraya, en su horizontalidad, esta idea de supeditación. El análisis de cómo se ha representado al maestro no puede olvidar la intencionalidad y el sentido que el autor, con formación artística, introduce para su comprensión. Los recursos visuales están subordinados a principios ideológicos, el profesor es una figura de autoridad que infunde respeto, pero los modos de alcanzar ese resultado pertenecen al artista y tienen una fundamentación formal. Esta búsqueda desde presupuestos que determinan la propia naturaleza de la imagen o que residen en el trabajo y el "oficio» del que la diseña, regirán el análisis de este artículo

Un número importante de grabados y dibujos realizados entre el siglo XVII y el XVIII protagonizados por maestros y aprendices no perseguían una finalidad educativa. La mayoría constituían lo que llamamos estampas (De Blas, 1994), es decir, 


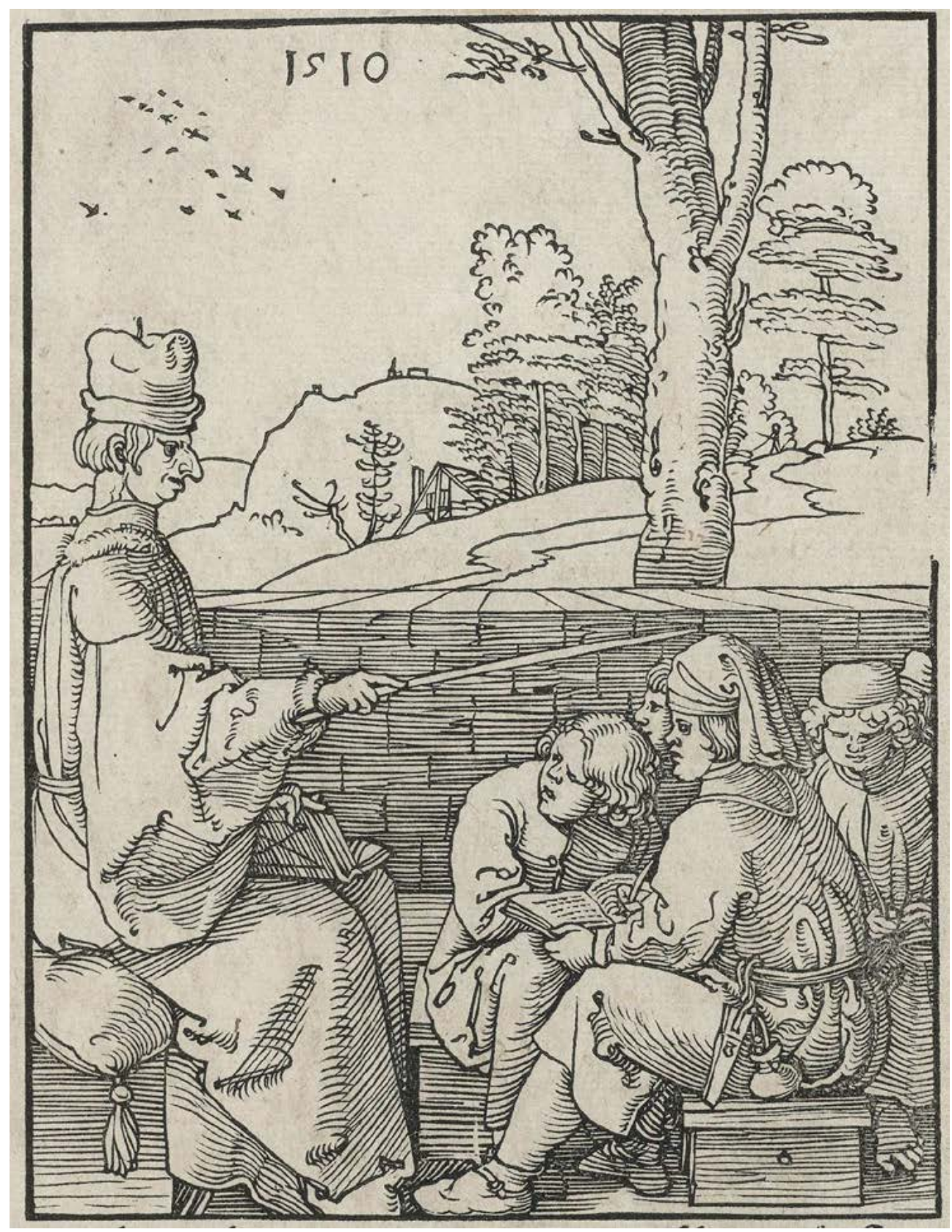

Fig. 01. Alberto Durero. El maestro de escuela. 1510. Xilografía. 127x98 mm Imagen procedente de los fondos de la Biblioteca Nacional de España. 


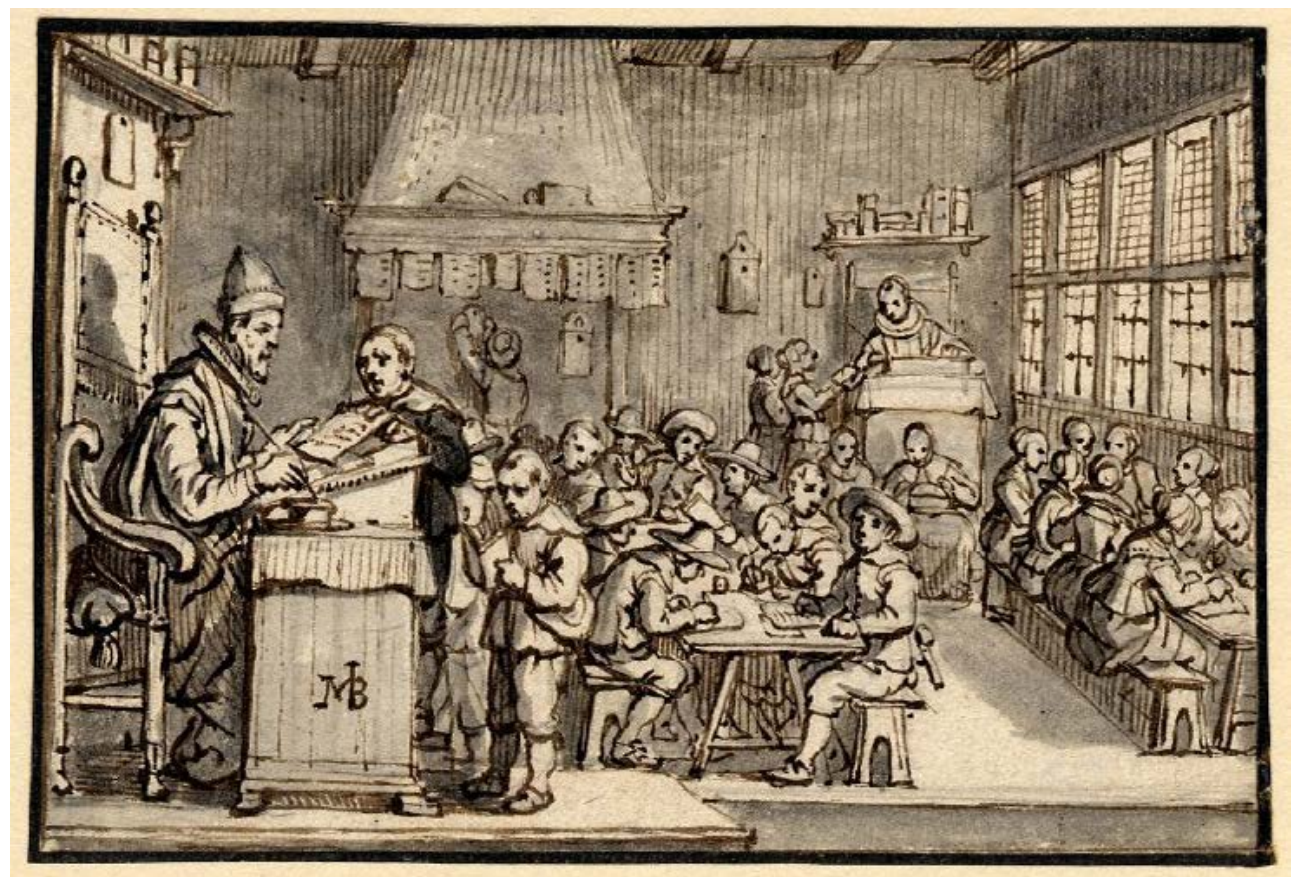

Fig. 02. Jan Martsen (atribuido). El maestro de escuela. 1624-1638. Dibujo invertido. 70x106 mm. (C) The Trustees of the British Museum.

imágenes originadas mediante distintas técnicas de impresión empleadas para fines diferentes. En gran medida muchas de ellas, aunque no solo, atendían al entretenimiento de quienes las adquirían. Algunas eran guardadas para ser contempladas en gabinetes dedicados para ello, otras se colocaban en las viviendas a la vista de sus propietarios.

Un conjunto de ellas reflejarán la idea de una escuela ordenada y armoniosa, regida por el que enseña quien, a menudo, blande en su mano el instrumento de castigo. Las composiciones representan, a diferencia de la de Durero, espacios interiores, cerrados, amplios y claros donde el maestro adopta una actitud comprensiva a la que los alumnos responden con aspecto dócil. Estos lugares albergan a niños de clases nobles o acomodadas como los que ofrecen las estampas de Abraham Bosse (c. 1604-1676) (Collección British Museum 1874,0711.2031), o el interesante dibujo atribuido a Jan Martsen (1609-1648?) (Fig. 2), preparatorio de un grabado, que presenta el «aula» que comparten niños y niñas, separados y atendidos por un maestro y una maestra, respectivamente. En las dos representaciones los profesores aparecen sentados y muestran el mismo noble aspecto que sus alumnos. La claridad que transmite el lugar representado encuentra su complemento en las figuras de los educadores que, desde su estrado, atienden a los alumnos. La perspectiva lineal y 
la ordenada disposición de los escolares contribuye a transmitir esa sensación de armonía.

La pintura de género, interesada en captar la cotidianidad desde la proximidad, ampliará todo este universo visual de provecho y aprendizaje sumiso con la incorporación de la escuela rural. Las pinturas y las estampas originadas desde el siglo XVI en los Países Bajos aportarán escenas con aulas improvisadas en las casas, con maestros y alumnos paupérrimos. En la obra de algunas de ellas se mostrará esa carencia de un modo verosímil, transmitiendo, no obstante, la relación armoniosa entre todos los que intervienen en la acción. Ejemplos destacados de esta manera de reflejar el mundo escolar son algunos de los grabados y dibujos obra de Adriaen Brouwer (1605-1638), Jan Luyken (1649-1712), o Jan Josef Horemans el viejo (16821759), que tendrán su continuidad en el siglo siguiente en las estampas de tema escolar de maestros franceses como François Boucher (1703-1770) o Jean Jacques Boissieu (1736-1810) ${ }^{1}$, entre otros.

Esta representación fidedigna de la pobreza, ensalzando la pureza de su sencillez en el medio rural, caracterizará una visión idílica de ese mundo que se extenderá entre muchos creadores europeos de la segunda mitad del siglo XVIII y de los inicios del XIX. Una representación que alcanzará un gran éxito, si atendemos a la proliferación de este tipo de estampas, en varios países, y que, en alguno de ellos como Gran Bretaña, conformará un modo de entender la obra de género que protagonizarán artistas como George Morland (1763-1804) (Bove, 2018).

La obra de género, no obstante, incluirá un destacado sesgo que aportará a la representación del maestro otro gran conjunto de imágenes bien diferentes a las mencionadas: me refiero a las presididas por la comicidad y la brutalidad. Ya a mediados del siglo XVI, Peter Brueghel el viejo (1526/30-1569) (Orenstein, 2001), crea una estampa, grabada por Pieter Van der Heyden (c. 1530-1572) y publicada por Hieronymus Cock (1510-1570) (Fig. 3) que muestra una escuela rural en pleno desorden. Los alumnos dispersos por el espacio del "aula», con más aspecto de cuadra que otra cosa, portan libros y papeles adoptando posturas y actitudes grotescas. En el centro de la imagen el maestro se dispone a golpear a un pupilo en su trasero, mientras un asno, que utiliza anteojos, lee atentamente una partitura. Los textos que acompañan la imagen inciden en las dificultades o imposibilidad de modificar la ignorancia y utilizan para ello comparaciones provenientes de proverbios tradicionales, bien conocidos entonces y muy utilizados por Brueghel (Alpers, 1987, 311-316).

El desorden y el castigo, la respuesta de los niños ante el aburrimiento y el control y dolor físico, aplicado por el maestro mediante diferentes instrumentos entre los que destaca un aparatoso cucharón de madera, presidirán un notable número de pinturas

1 Véanse las referencias 1838,0420.111, 2AA+,a.57.80, 1927,0721.15, 1853,0312.361 de la colección del Museo Británico, así como la RCIN 912877 de la Real Colección Británica. 


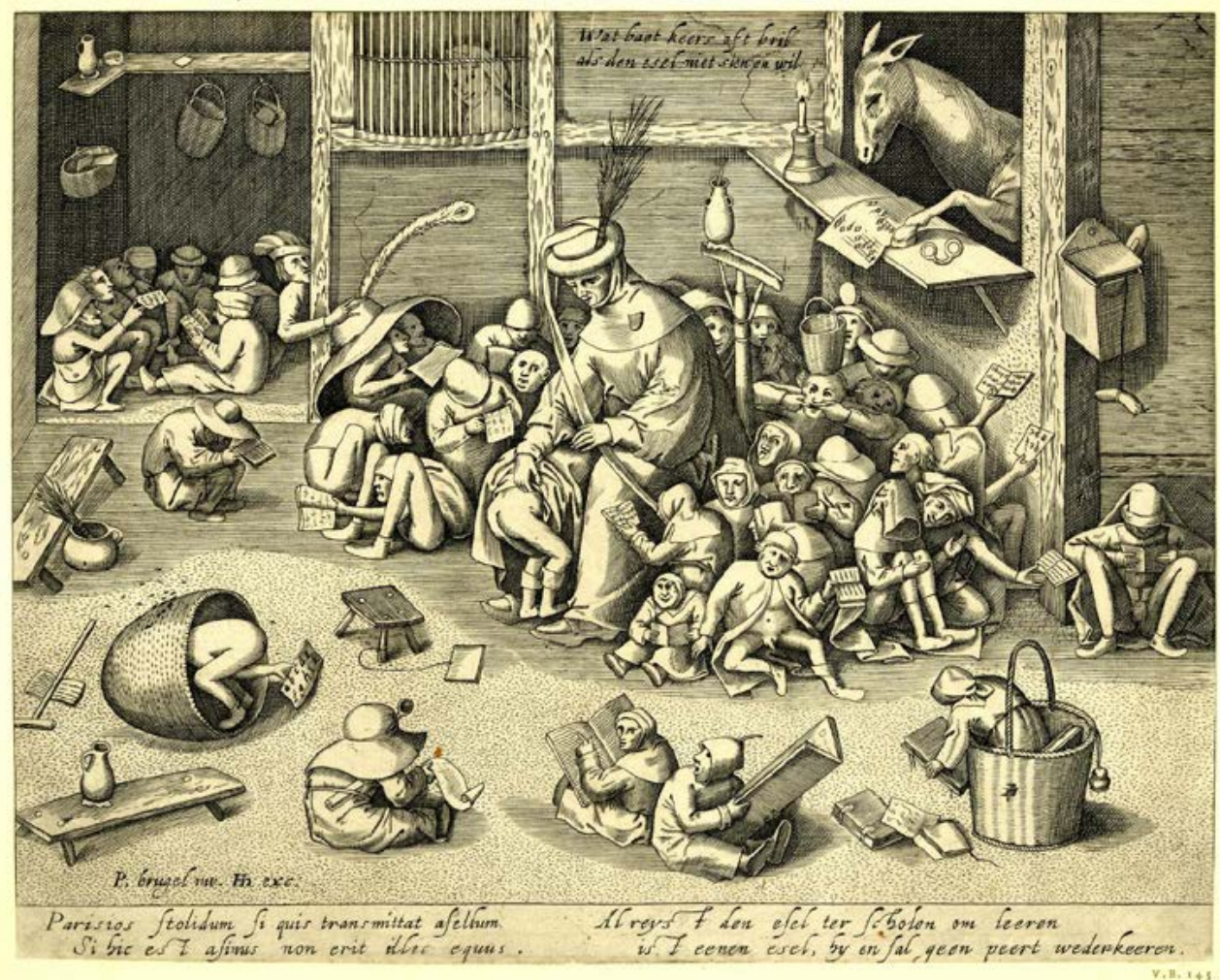

Fig. 03. Pieter Brueghel el viejo/ Pieter Van der Heyden. El asno en la escuela. 1597-1650. Grabado invertido. 229×293 mm. (C) The Trustees of the British Museum.

y grabados de temática escolar. No es de extrañar que estas obras procedentes de las manos de Adriaen Van Ostade (1610-1685), Jan Steen (1626-1679) o Egbert Van Heemskerck (1634-1704)², triunfaran por su carácter jocoso. Estampas con esta intención se reprodujeron y grabaron constantemente, destacando, de nuevo, su presencia en el ámbito británico (Mount, 1991). La mezcla de las travesuras y la violencia mostraba esa otra cara del aprendizaje en la escuela rural, muy diferente a la mencionada antes. Es a partir de estas últimas representaciones donde se fraguará una de las imágenes más populares del maestro en la Europa del siglo XIX.

Recientemente, una de estas imágenes ha sido objeto de atención en el ámbito investigador (Pozo, Braster, 2017). Se trata de una acuarela -The village school in an uproar- realizada en 1809 por el artista británico Henry James Richter (17721857). La acuarela, hoy desaparecida, tuvo una importante divulgación a través de

2 Veánse las referencias 1861,1109.217, 1861,1109.347, 2010,7081.101 de la colección del Museo Británico. 


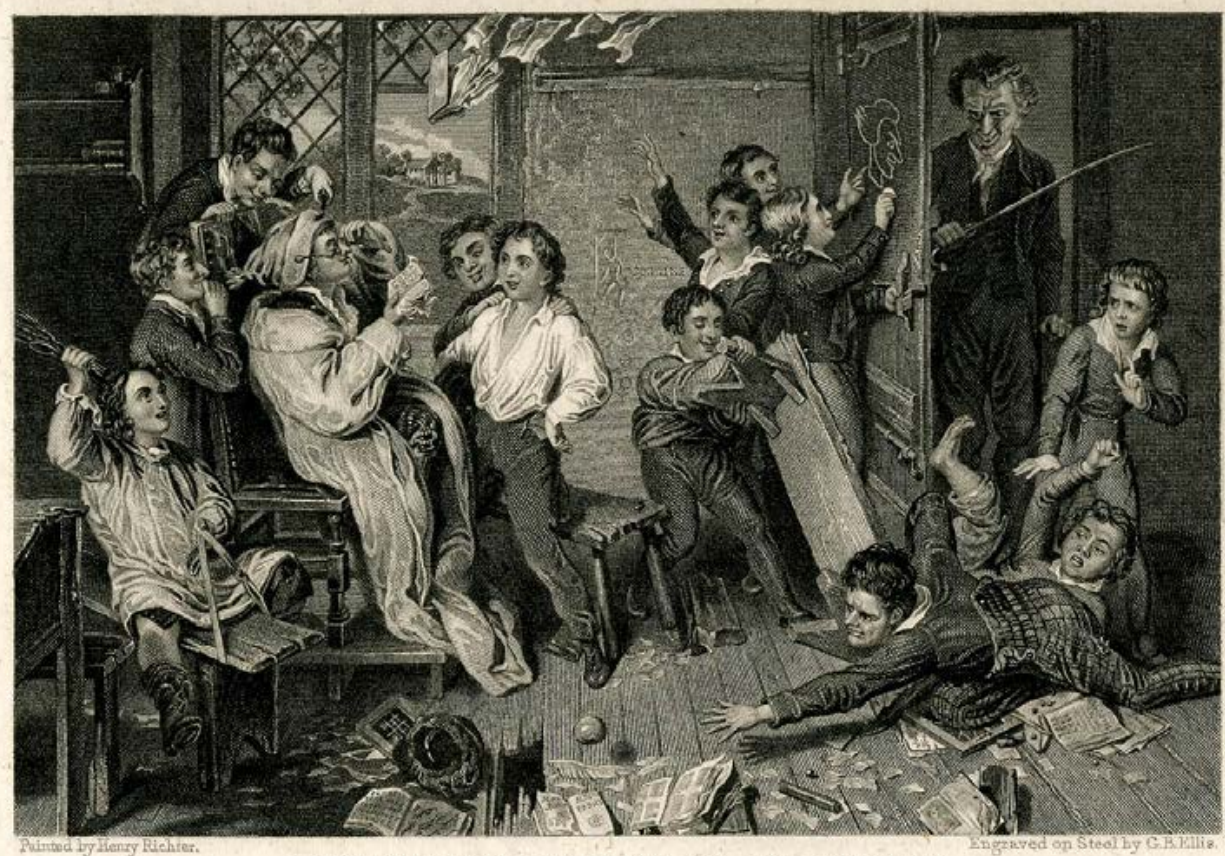

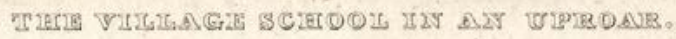

Fig. 04. Henry James Richer / George B. Ellis. The village School in an uproar. C.18211838. Grabado. $90 \times 147 \mathrm{~mm}$. (C) The Trustees of the British Museum.

los grabados y litografías que el propio Richter realizó posteriormente (Fig. 4). De este modo, fue reutilizada constantemente por otros dibujantes. Varios grabados del caricaturista británico George Cruikshank (1792-1878) realizados en 1826 y $1843^{3}$, o, mucho después, la ilustración del dibujante español José Giménez, quien en 1871 la reinterpreta en la prensa infantil española - Los Niños nueve de abril-, son algunos ejemplos de su enorme difusión. La imagen creada por Richter nos dirige hacia uno de los ámbitos en los que la representación del maestro va a retroalimentarse: la caricatura.

Efectivamente, cocinada en la pintura de género e interpretada a través de la deformación caricaturesca, utilizada en estampas y en la prensa periódica de toda Europa a partir de la segunda mitad del XVIII, se conforma una representación cómica y peculiar del maestro. Este aparecerá tocado con un gorro de dormir o un bonete, cubrirá su cuerpo con un gabán o una bata, en sus pies llevará unas zapatillas caseras o calzado en mal estado. Su aspecto se completará con una larga vara para señalar y castigar, la fusta o, en las más retardatarias, el haz de ramas o el

\footnotetext{
${ }^{3}$ Veánse las referencias 1853,0112.266, 1978,U.2671 de la colección del Museo Británico.
} 


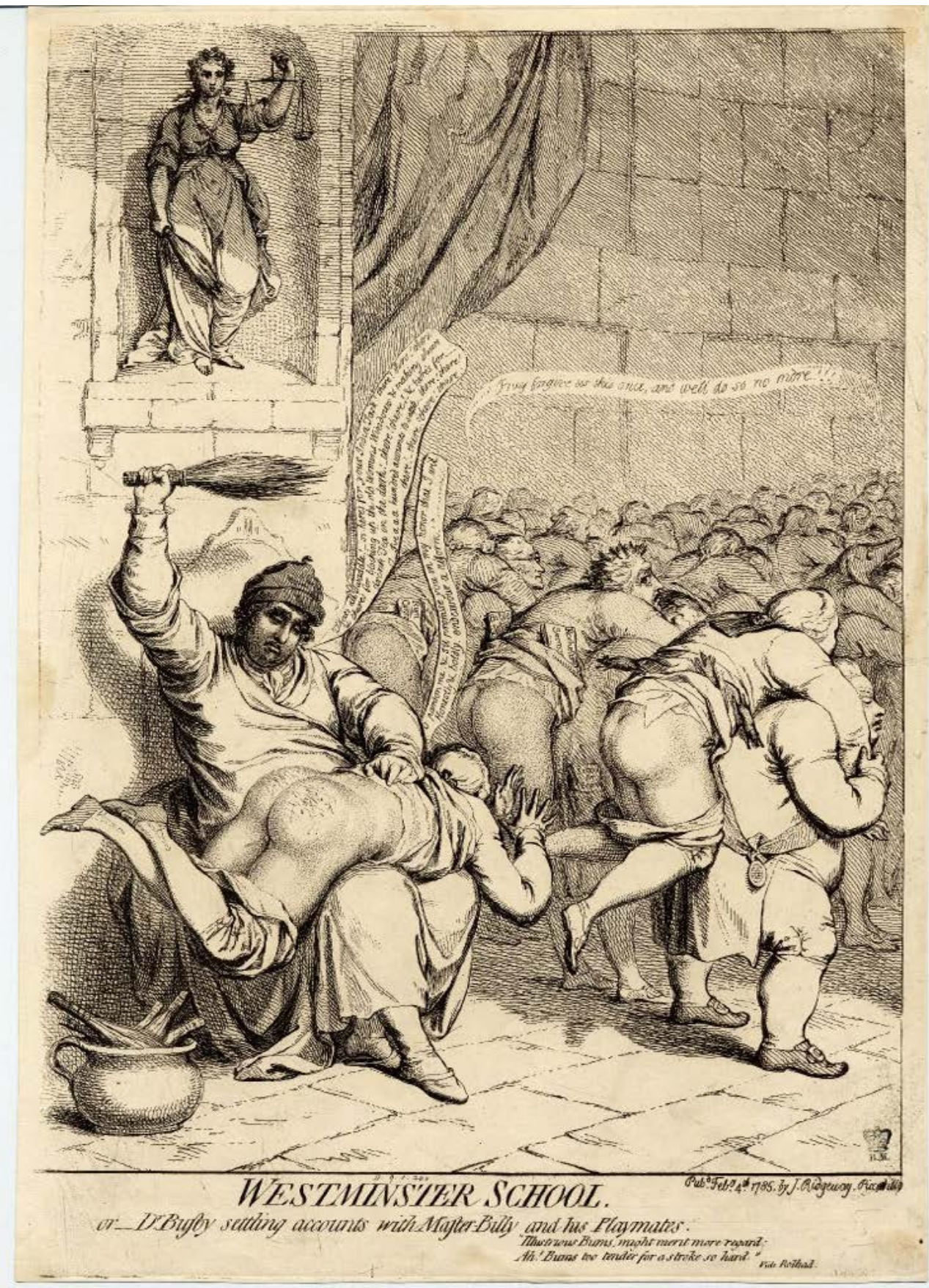

Fig. 05. James Gilray/James Ridgeway. Westminster school. or-Dr Busby settling accounts with Master Billy and his playmates. 1785. Grabado. $360 \times 260 \mathrm{~mm}$. (C) The Trustees of the British Museum. 
mencionado cucharón de madera que blande en su mano. Este aspecto está presente en la parodia que los alumnos hacen del maestro en la estampa de Richter.

La caracterización se halla, no obstante, en algunos de los ejemplos flamencos mencionados y en estampas anteriores y muy cercanas en el tiempo a esa obra de Richter. Por ejemplo, en la realizada por James Gillray (1757-1815), publicada en 1785 con el título de Westminster School, (Fig. 5) en la que la sátira de la política se materializa en la figura del maestro - C. J. Fox - que castiga con el haz de varas de abedul a un alumno adulto - Pitt- y sus seguidores. $O$ en otras anteriores, instruyéndonos, por cierto, en el modo de golpear en esa época el trasero del alumno manteniendo al azotado "a caballo" de su compañero que le inmoviliza los brazos (Bullard, 2019). Esta caracterización del maestro estaba muy difundida en Gran Bretaña, como puede apreciarse en el grabado a la mezzotinta de John Faber el joven en 1739 a partir de un dibujo de Philippe Mercier (c. 1689-1760) presente en la colección del Museo Británico de Londres (Museum number 2006, U.471).

\section{LA IMAGEN DEL MAESTRO CONCEBIDA COMO OBJETO DE DIVERSIÓN Y CRÍTICA}

Esta representación, convertida en la referencia visual del maestro vinculada a la comicidad o la crítica, curiosamente, ofrecerá alguna variante en España al confundirse o entremezclarse con la del instructor conocido como dómine (Escolano, 2006, 37). Para entender el modo en el que oficios y personajes se convierten en tipos debe atenderse a los estudios realizados por Valeriano Bozal sobre este asunto (Bozal, 1979, 75-83).

El dómine, profesor de gramática latina vinculado directa o indirectamente a la Iglesia y presente en la tradición española desde el siglo XVII, asumirá en nuestro país los rasgos arquetípicos del maestro. Para entender la vigencia de este "tipo», no debe olvidarse la popularidad que alcanzó la revista Fray Gerundio publicada entre 1837 y 1844 por Modesto Lafuente (1806-1866) (Fuentes Arboix, 2014). Dicha publicación, intercalaba grabados con la imagen de Fray Gerundio, un dómine, y su ayudante Tirabeque. La presencia - como un tipo español- del dómine en un texto ilustrado tan popular como Los españoles pintados por sí mismos aparecido en 1843-44 (Fig. 6) y reeditado en 1851 (Bozal, 1980), permitirá reconocer los rasgos que la imagen satírica del maestro decimonónico español empleará, a caballo entre ese maestro rural con su haz y cucharón, procedente de los Países Bajos y Gran Bretaña, y el dómine español con su fusta y su levita (Fig. 7).

Durante la Restauración la representación del maestro tendrá una presencia notable en la prensa satírica para adultos al ser considerado uno de los "oficios útiles» maltratado por la sociedad (Bozal, 1978, 220). Durante los primeros años (1876-1885), el maestro, reflejo de un sistema escolar no demasiado extendido y, 


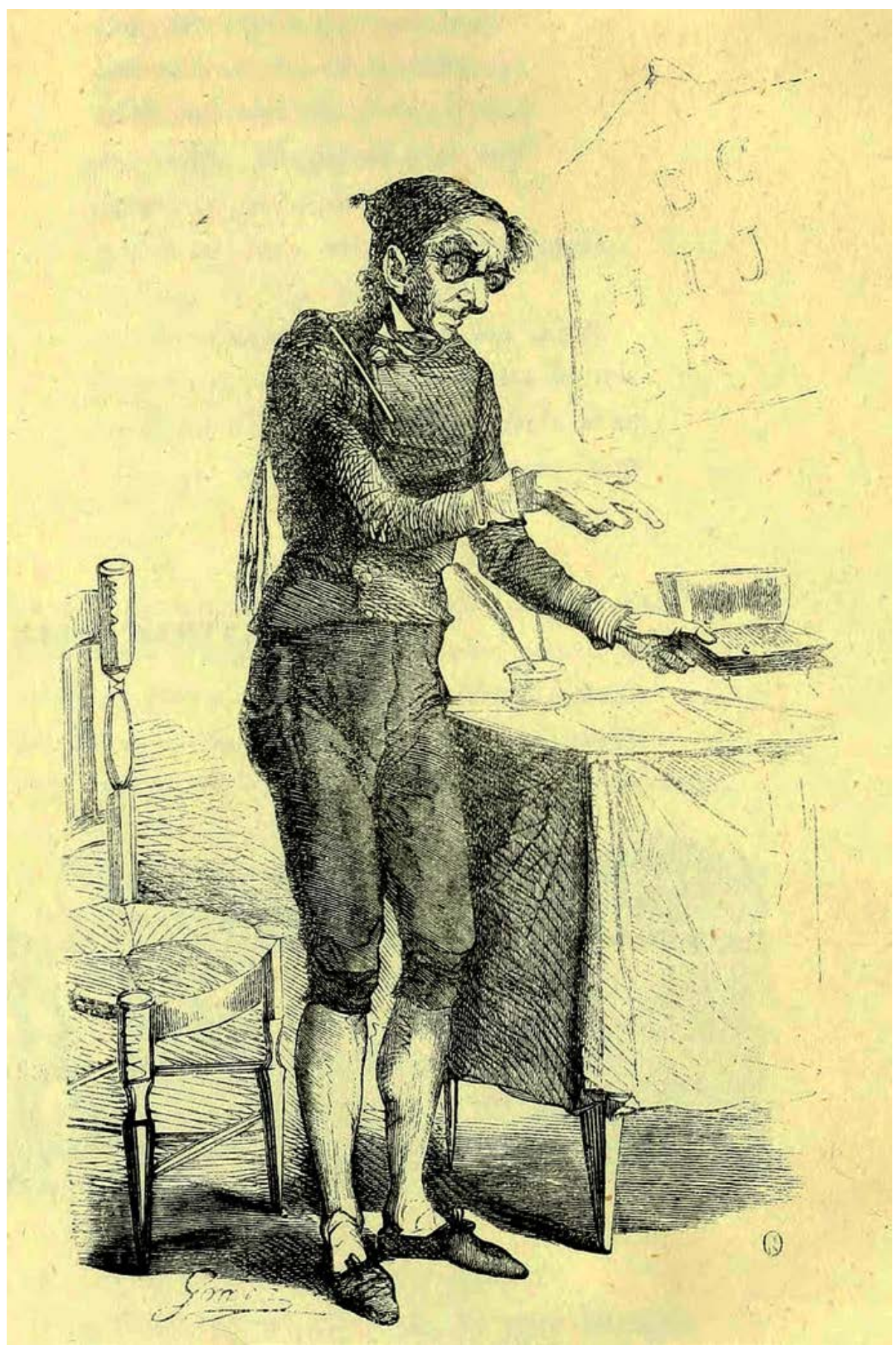

Fig. 06. Antonio Gómez/Calixto Ortega. El dómine. Xilografía. Los españoles pintados por sí mismos. 1843. Madrid. Ignacio Boix. Vol. 1. $26 \mathrm{~cm}$. Mancha $124 \times 89 \mathrm{~mm}$. 


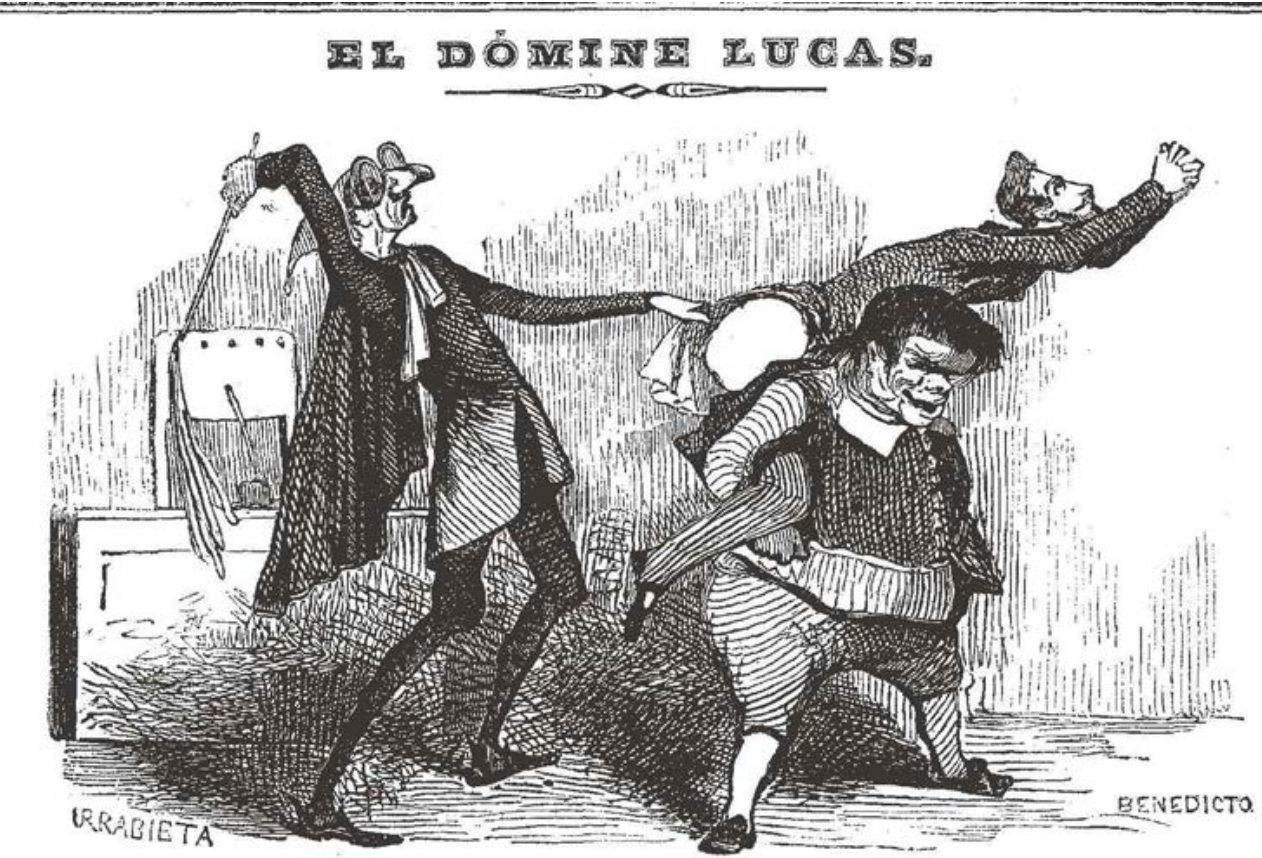

Fig. 07. Vicente Urrabieta/Benedicto. El dómine Lucas. Xilografía. Anuncio de la enciclopedia del mismo nombre. La Risa 17 de marzo 1844, p. 192. 26 cm. Imagen procedente de los fondos de la Biblioteca Nacional de España.

sobre todo, escaso de recursos, aparecerá a menudo en esa prensa jocosa. Encarnará la pobreza, el hambre y, en las revistas más críticas, será un producto ignominioso de una sociedad ignorante que ensalza a toreros y nutre a curas orondos. Mariano Urrutia Parra (¿'?-1894) (Bozal, 1978, 218) lo representará en la calle ante un cartel de una vedette (Fig. 8), con el aspecto de un pordiosero lamentándose de su hambre frente a la salud de la mujer curvilínea. En este dibujo publicado en 1877 en la revista Fray Verás de Madrid, el maestro no presenta los rasgos propios del tipo al que estamos aludiendo, pareciendo más bien la representación de otro, tal vez del artista, reaprovechada para ilustrar un tema tan candente como el de la Educación.

Muchas menos dudas de la secuencia y caracterización formal a la que estoy aludiendo la ofrecen dos ilustraciones publicadas en L'Esquella de la Torratxa de Barcelona en 1879. La primera, posiblemente realizada por Jaume Pahissa Laporta (1846-1928) (Soler, 2004, 14) ofrece la portada del número 40 del 25 de octubre dividida en dos partes mediante un atril coronado por un prócer con cabeza de burro que muestra dos escudos (Fig. 9). En el lado izquierdo, la imagen del torero triunfante en la plaza a cuyos pies se acumulan los obsequios, fumando un puro, signo inequívoco en España, durante mucho tiempo, del poder económico. En el otro, la caricatura cadavérica del maestro con bonete y gabán, que, como el resto 


\section{EL MAESTRO DE ESGUELA.}

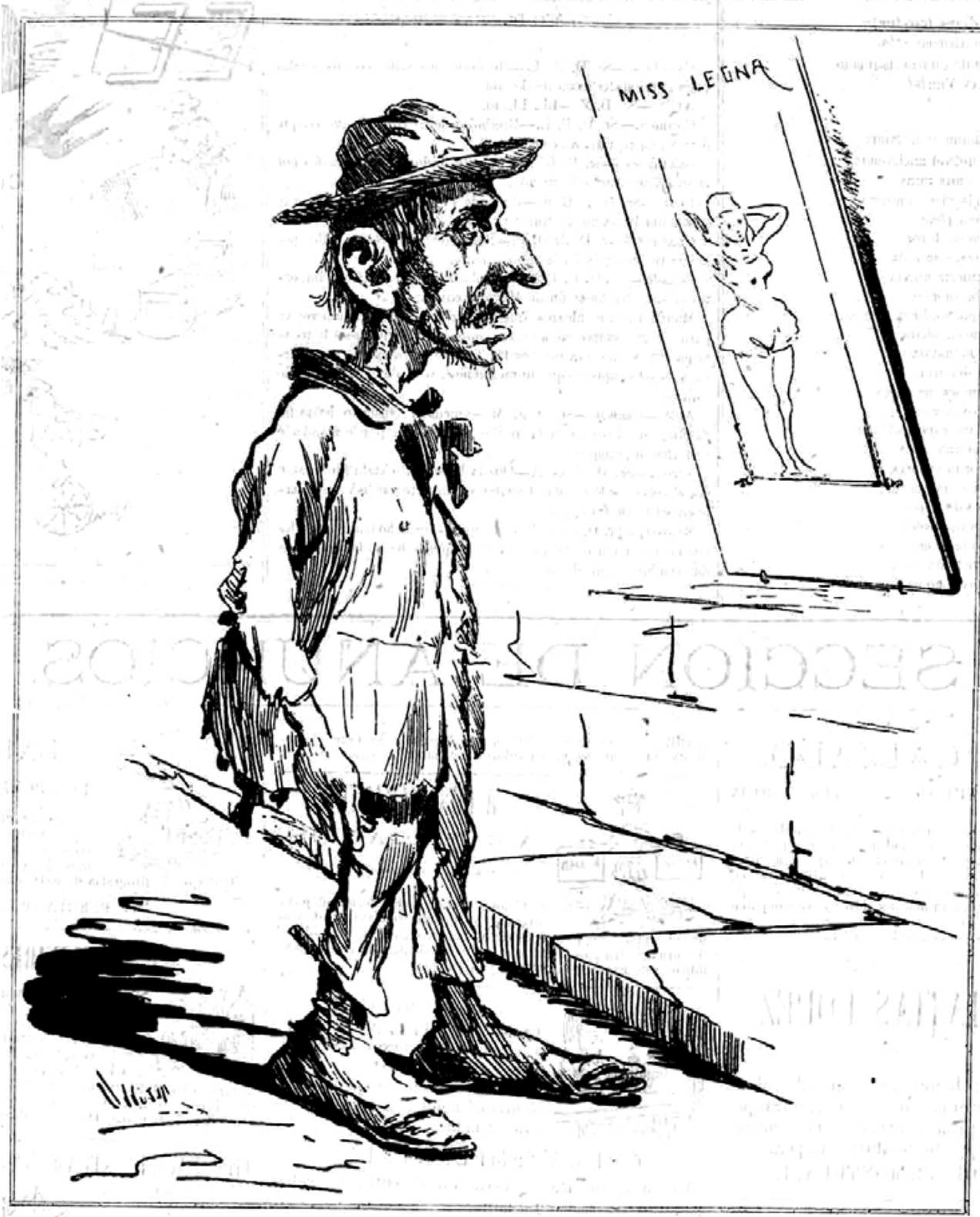

-Si yo tuviera, como tú, mandíbulas de hierro, habíame tragado el mundo.

Fig. 08. Mariano Urrutia. El maestro de escuela. Fray Verás, 27 de octubre 1877, p. 3. $44 \mathrm{~cm}$. Imagen procedente de los fondos de la Biblioteca Nacional de España. 


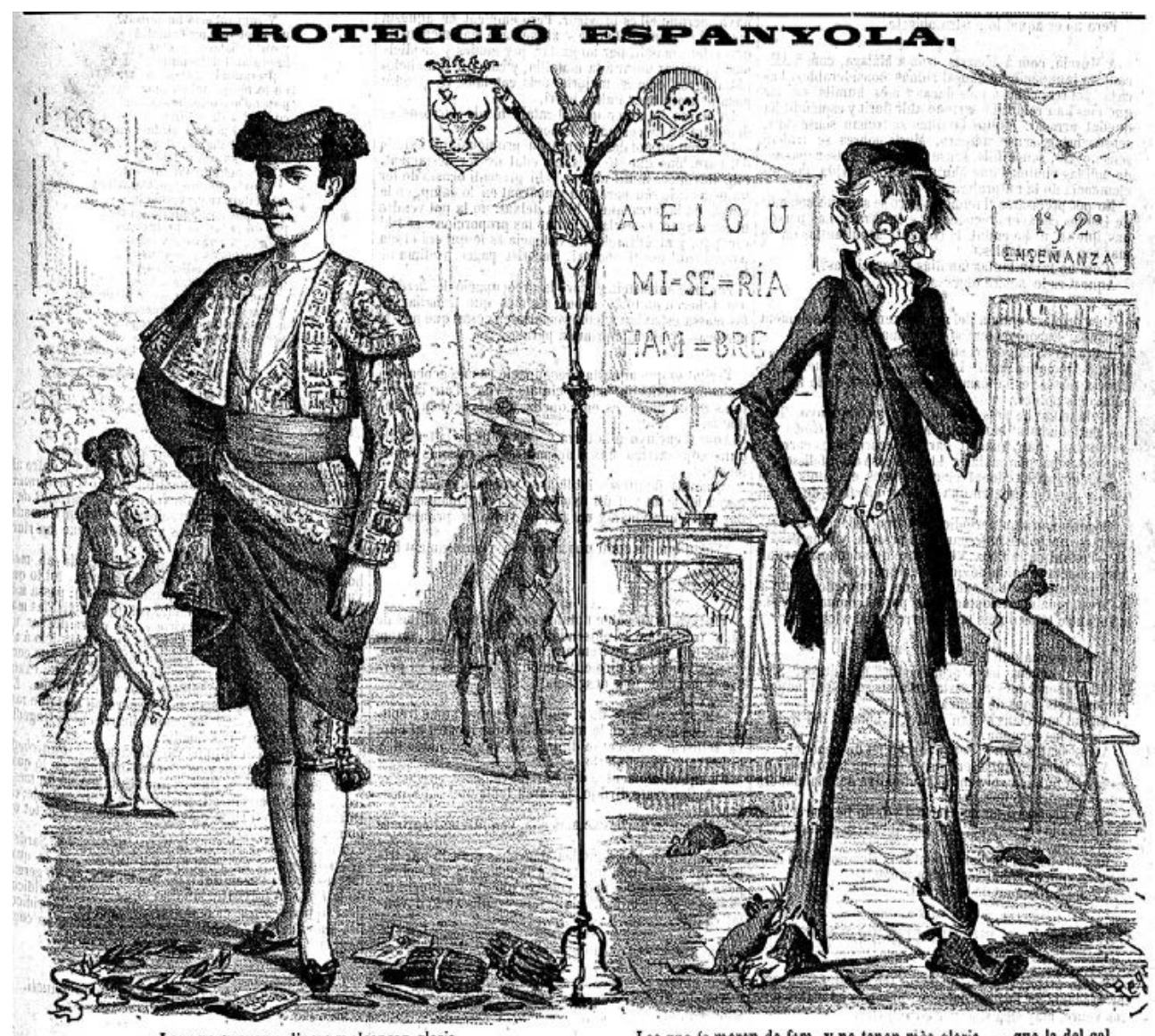

Los que guanyan diners y alcansan gloria.

Los que 's moran de fam, y no tenen mès gloria..... que la del cel.

Fig. 09. Jaume Pahissa ¿?. Protecció española. Litografía. L’Esquella de la Torratxa. 25 de octubre de 1879.

de su ropa, componen un auténtico harapo, situado en el interior de una escuela de "primera y segunda enseñanza» acompañado por las ratas.

Dos números después del mencionado -en el 42-, Apeles Mestres (18541936) (Armangué, 2007), con motivo de las inundaciones de ese otoño, utilizará al maestro para indicar la ausencia de ayudas para la población.

Mucho más evidente es la imagen publicada en El Loro de Barcelona el 3 de julio de 1880 (Fig. 10), una magnífica litografía de Jaume Pahissa. La doble página central, a todo color, retoma la comparación entre el torero y el maestro, empleando, como en las anteriores, a los clérigos como caracterizadores de la sociedad ignorante que, para estos medios de comunicación republicanos y anticlericales, representa el sistema político de la Restauración. En esta imagen, ubicada en una ciudad en la que destacan la plaza de toros y las torres de las iglesias, el maestro, que sale de una escuela 


\section{DOS INSTRUCCIONES QUUE SE PROTEJEN}

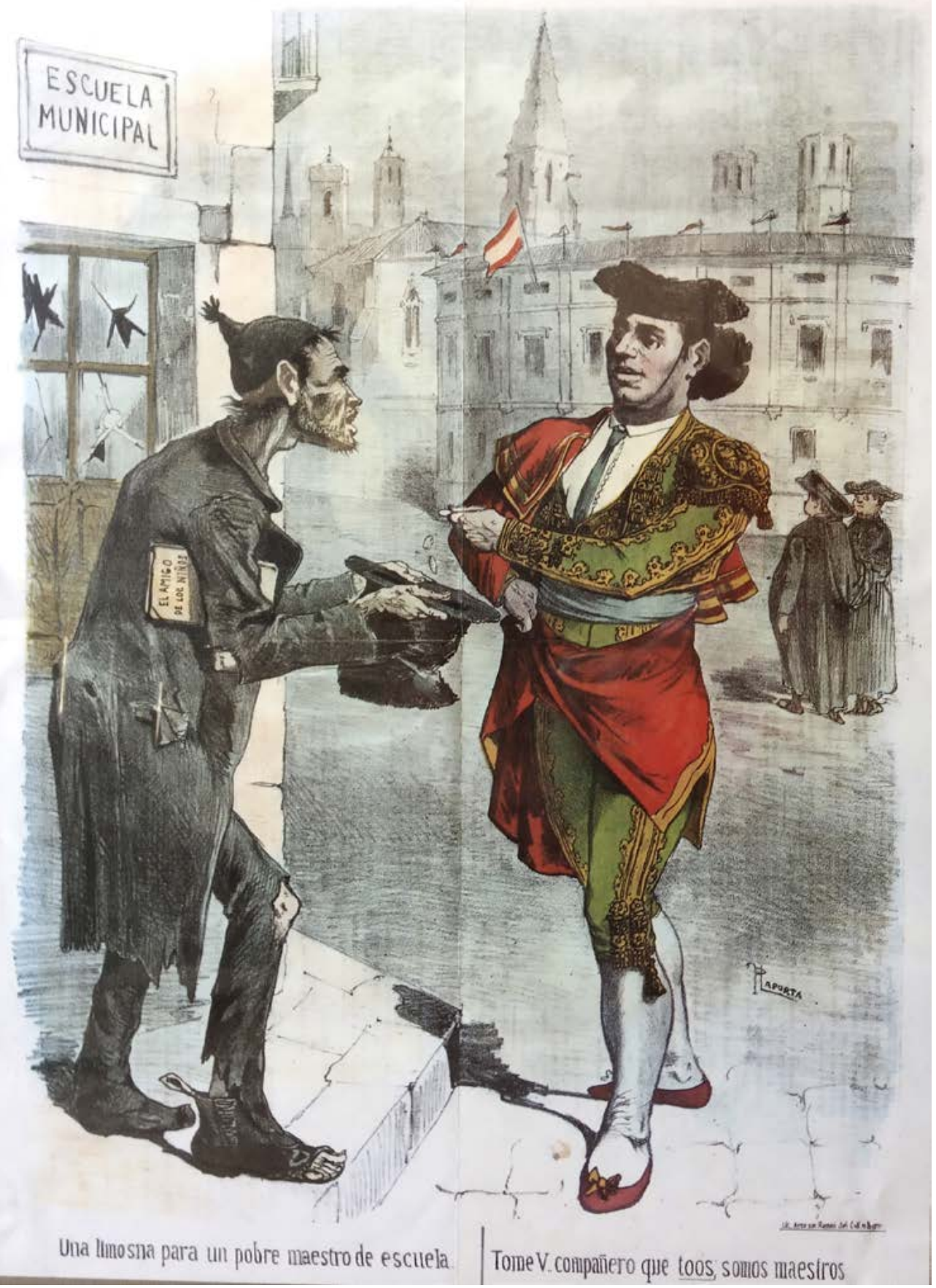

Fig.10. Jaume Pahissa. Dos instrucciones que se protejen. Litografía a cuatricomía. El Loro. 3 de julio de $1880.40 \mathrm{~cm}$. (doble página). 
municipal con los cristales de sus ventanas rotos, pide limosna al torero que, identificándose de forma chusca con la maestría en el pie de texto, deja caer unas monedas en el viejo sombrero que le ofrece el profesor.

Esta ilustración, como las anteriores, incide en un problema que arrastraba la educación pública de la época. El mantenimiento y sustento de escuelas y maestros era, desde que se desarrolló la primera Ley de Educación de 1857, e incluso antes, función de los municipios. Esta situación no cambió algo hasta la promulgación del Real Decreto de 26 de octubre de 1901, conocido como Ley Romanones por la que el Estado asumía los sueldos de los maestros (Briongos, 2015). El maestro de nuestra imagen, vestido con los harapos y el gorro que lo identifican con el antiguo dómine, lleva bajo su brazo derecho el libro El Amigo de los Niños, que escribiese el jesuita francés Joseph Reyre (1735-1812) y que era todavía muy popular en las escuelas españolas (Castelani y Zapata, 2007, 160-182).

La imagen utiliza la iconografía popular del maestro originada en la estampa europea de la escuela rural y en la del dómine español como un medio, útil y de gran eficacia comunicativa, para la denuncia. En ambos casos los elementos ambientales, el espacio donde las figuras se encuentran y todo lo que las acompaña - edificios, calles, objetos y personajes - tienen suma importancia. No obstante, la forma de construir ese espacio como de determinar las figuras es bastante convencional, apoyándose en la tradición académica y en la representación de tipos a la que he hecho alusión más que en su deformación caricaturesca.

La ilustración realizada por Eduardo Saénz Hermúa «Mecachis» (1859-1898) (Casado, 2006, 181-182), publicada como "portada» de La Caricatura el 30 de septiembre de 1885 , ofrece mayor proximidad a la caricatura. En ella se vuelve a aludir al hambre que sufre el profesor, caracterizándolo de un modo parecido al que acabo de analizar, aunque aparezca parapetado tras su mesa, aportando el sentido del humor de quien fue uno de los primeros artífices de la historieta gráfica española (Martín, 1978, 21-25).

Toda esta producción no llega a alcanzar la intensidad y variedad de las realizadas en países vecinos como Francia, algunos de cuyos dibujantes fueron muy influyentes en la ilustración satírica española. Debe citarse, en este sentido, la fantástica serie dedicada al mundo escolar que llevó a cabo Honoré Daumier (1808-1879) bajo el nombre de Professeurs et Moutards que fue publicada entre el 2 de diciembre de 1845 y el 14 de junio de 1846, en Le Charivari (VV. AA., 2008).

Es importante, llegados a este punto, que nos preguntemos por la relación de esta caracterización del maestro, utilizada en gran medida para interpelar a un público adulto, y los repertorios visuales dedicados a la infancia. Es decir, si este maestro maltrecho, vestido con una indumentaria tan doméstica que, sin duda, quiere identificar su residencia con la escuela, ilustra algún producto destinado al público infantil en este mismo periodo en España. Es preciso indicar que sí, pero que lo hace solo en obras de ficción y que las fechas de su aparición son tardías. 
Existen varios ejemplos que proceden de la Editorial Sopena, fundada en Barcelona en 1894 por Ramón Sopena López (1867-1932) (Rivalan-Guégo, 2013), cuyos libros destinados al público infantil comienzan a publicarse alrededor de 1917. El primero corresponde al trabajo realizado por el caricaturista belga Didier Dubucq (Doyzy, 2007), conocido como Asha o Ashaverus. En el contexto de una serie de cuadernos a todo color protagonizados por un pilluelo llamado Pirulete (García, 2004, 46) muestra una escuela (Fig. 11). Asha, utilizando procedimientos plásticos propios de la historieta gráfica como la simplificación de líneas y colores, la utilización de composiciones mediante diagonales muy marcadas, un fuerte contraste lumínico y la representación de objetos y figuras en movimiento, obtiene resultados de gran intensidad. En ellas el maestro refleja la indumentaria propia de su visión caricaturesca, con bonete, gabán, fusta y un monigote de papel en su espalda.

El segundo lo forman una serie de imágenes elaboradas por Luis Palao Ortubia (1863-1930), el principal ilustrador de la casa Sopena. Realizadas hacia los años veinte del siglo pasado para ilustrar una serie de cuentos para niños, ofrecen la peculiaridad de estar protagonizadas por animales humanizados. Este es un género con una larga tradición a sus espaldas que entronca con la sátira en la literatura y la representación artística. Sus orígenes plásticos pueden rastrearse, por no remontarnos a modelos más antiguos, en las mismas pinturas de género flamencas a las que se ha hecho alusión. Además, su entronque con las fábulas de origen grecorromano y las narraciones procedentes de oriente, han permitido que las imágenes protagonizadas por animales humanizados hayan estado presentes en la génesis y el desarrollo de la caricatura de los siglos XVIII y XIX. No es ajena a grandes creadores como Goya (1746-1828) quien la utiliza en sus Caprichos y alcanza un notable protagonismo en la obra de dibujantes como Grandville (1803-1847).

La presencia de animales humanizados en los productos editoriales dedicados a los niños, sin renunciar a este origen satírico, va a aprovechar la empatía que los protagonistas animales producen en la infancia y la libertad emocional que proporcionan sus acciones, tan animales y... tan humanas. En este sentido no puede obviarse la llamativa producción de narraciones infantiles ilustradas con animales editadas en Gran Bretaña desde los primeros años del siglo xIX (Bozal, 1989, 106-107). La influencia británica es evidente en las casas editoriales españolas que emplean este tipo de protagonistas (Gil-Díez, 1987). En el caso al que estoy haciendo referencia el influjo es evidente, pues Sopena publicará en español algunas obras de la editorial británica Cassell, ilustradas por Harry B. Neilson (1861-1941).

Palao se inspirará en este ilustrador y en otros, también británicos, hasta rozar el plagio. Pese a ello, los maestros andrajosos que representa habitando una destartalada escuela animal, componen un rango de verosimilitud y crudeza que no 


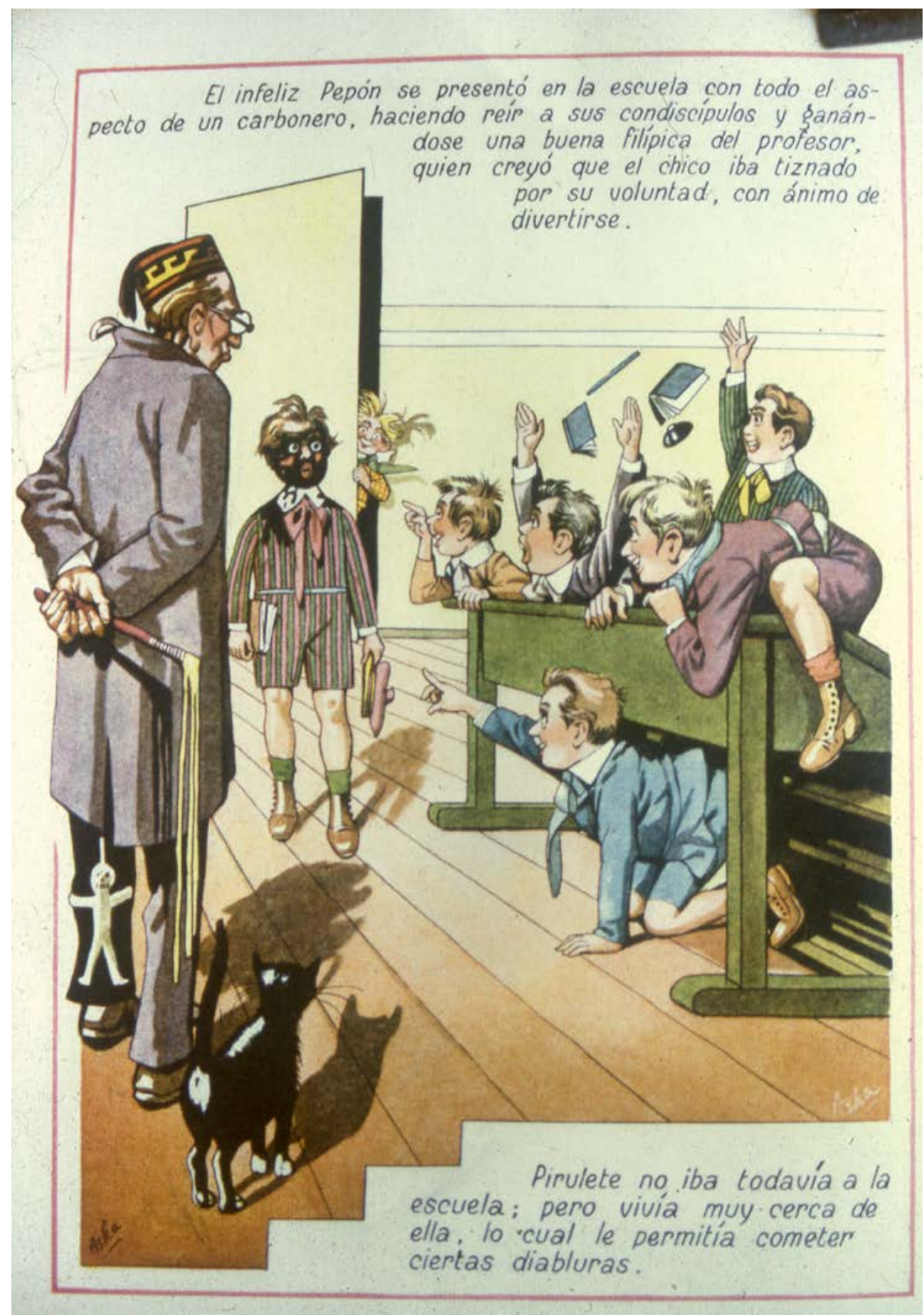

Fig. 11. Asha (Diier Dubucq). Pirulete en la escuela. Barcelona: Sopena, s.a. $28 \times 20 \mathrm{~cm}$. 


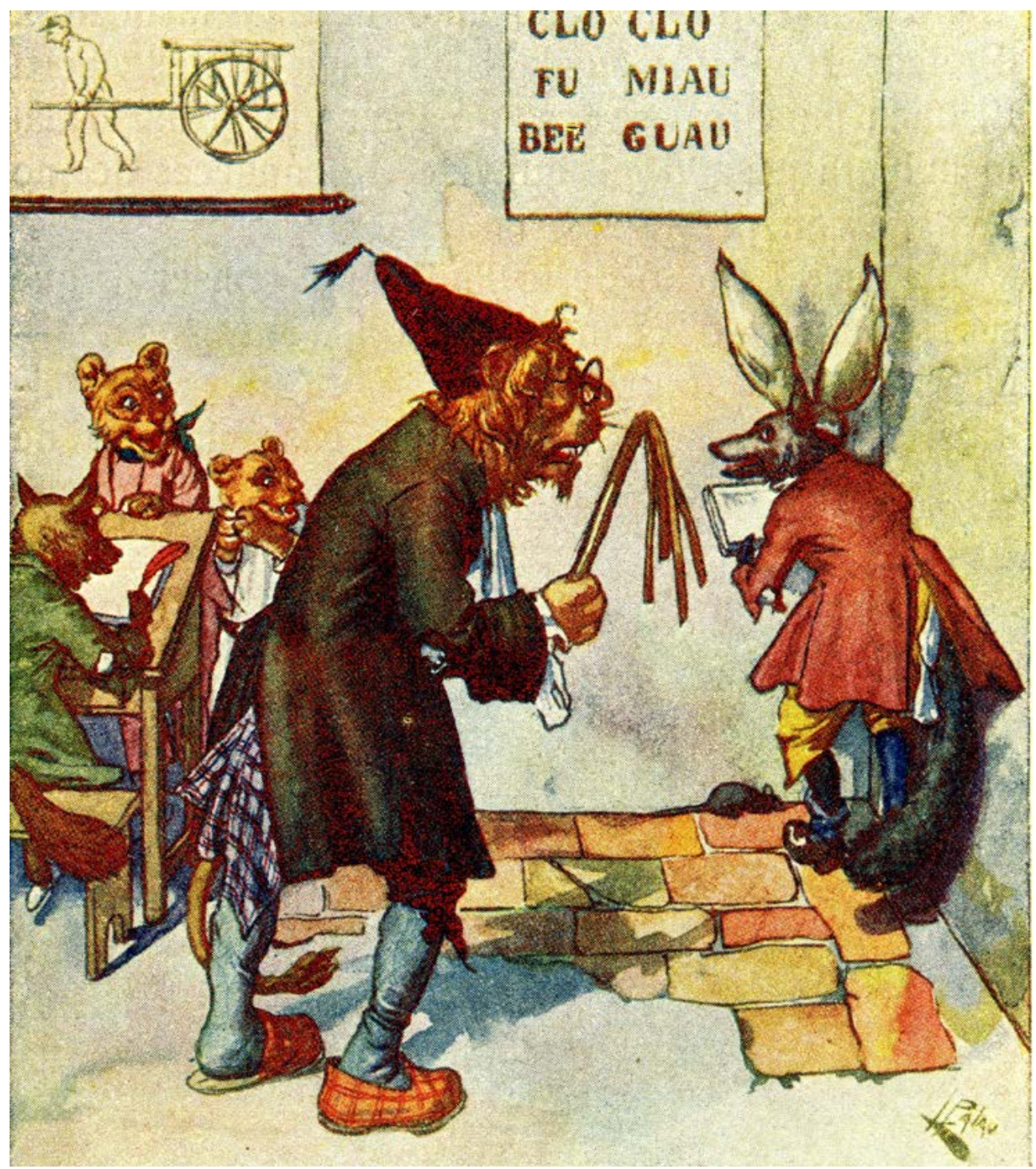

Fig. 12. Luis Palao. El león Melenas I. Barcelona.: Sopena. s.a. 16,5x 12,5 cm.

tenían en el trabajo de Neilson (Fig. 12). Las ilustraciones de Palao aportan una visión detallista cercana a la sordidez. El naturalismo que embarga la imagen acentúa el desgarro de ese profesor pobre, o el carácter doméstico de su indumentaria, así como del aula en la que se sitúa. Una pobreza heredera de las ácidas representaciones de finales del siglo anterior, pero enfundada en la piel de un león o un oso con la pretensión de divertir, no de denunciar (Fig. 12). 


\section{LA REPRESENTACIÓN DEL MAESTRO COMO HERRAMIENTA DEL SISTEMA ESCOLAR}

La imagen del maestro no ha sido solo motivo para la diversión o el entretenimiento inserta en narraciones y lecturas, o de corrosiva crítica ilustrando publicaciones periódicas de carácter satírico. Los libros para escolares utilizados en el aprendizaje también han empleado esta representación para afirmar o reforzar el sistema escolar. La representación de la escuela y el maestro ha aparecido de forma escasa en libros para escolares españoles editados antes de 1876. En España, los libros infantiles apenas contienen ilustraciones antes de esta fecha. De hecho, el despertar del libro ilustrado español infantil coincide más o menos con el arranque de la Restauración borbónica.

Esta utilización de la imagen de la escuela, como mera ilustración de un texto, puede apreciarse, no obstante, en alguno breves ejemplos en la España anterior al último tercio del xIX. Un tosco grabado anónimo aparecido en el número 47 de la publicación periódica Museo de los Niños de 1843 acompaña a un texto en el que un adulto acude a una escuela ubicada en un piso madrileño en el que se premia a dos niños por su aplicación. La sencillez de este grabado, seguramente obtenido de una matriz de madera, sirve para introducirnos en un grupo de imágenes que, en un entorno de armonía escolar, reflejarán la virtud del aplicado y su recompensa.

Debo indicar que estas ilustraciones se incluyen en textos para la lectura, en narraciones que pretenden contribuir al perfeccionamiento de la capacidad lectora de los alumnos, introduciendo una finalidad ejemplificadora que potencie actitudes de sumisión y armonía con la institución escolar, de la que el maestro o el inspector serán sus figuras más destacadas. Aunque no es fácil distinguirlos, pues los márgenes entre ellos son a veces escasos, se podrían diferenciar los textos dedicados a regular el comportamiento de los alumnos, a los que pertenecen las cartillas y libros de Urbanidad, de los libros de lectura que pretenden ampliar la capacidad de esta habilidad sin dejar de orientarlos en su comportamiento (Escolano, 2006, 219-239).

Un grupo destacado de estas representaciones escolares están dedicadas a escenificar algún tipo de reprimenda. Son pues escenas de castigo y premio. Si buscamos antecedentes europeos a este tipo de imágenes en un medio similar, es decir, en libros infantiles con carácter escolar, se puede señalar, en la segunda mitad del siglo XVIII, los grabados en madera generados por Thomas Bewick (17531828). Estas ilustraciones acompañaron alguno de los libros de lectura más populares en las escuelas de Gran Bretaña como Las Fábulas de Esopo, las Memorias de una peonza de Mary Ann Kilner. (1753-1831) o manuales para el aprendizaje de la lengua como el de Daniel Fenning (1714/15-1767). También la colección de Himnos morales de Isaac Watts (1674-1748). En todos estos libros, ornamentados por Bewick, se aprecian escenas que con gran sencillez y economía de recursos 
muestran a grupos de escolares junto a su profesor. La escuela que representan estos grabados no parece tal, se ubica en cálidos salones en los que la chimenea está presente. Los profesores aparecen a menudo cómodamente sentados mientras que sus alumnos, colocados en bancos frente a una mesa común, trabajan. En la mayor parte de estas representaciones la escena se completa con un escolar en pie leyendo o recitando bajo la amenaza del castigo con el haz de ramas. Los maestros están vestidos como caballeros excepto en una de ellas que, curiosamente, lo muestra, como era habitual, con un atavío mucho más casero que incluye el gorro y algo similar a una bata.

La utilización de estas representaciones adquiere en el final del siglo XIX en España un cariz emblemático. Acompañando los libros de lectura, fijarán visualmente los riesgos y las recompensas que conllevaba el comportamiento de los alumnos. Del conjunto de libros ilustrados dedicados a señalar y advertir sobre esa conducta adecuada, me voy a detener en unas imágenes que acompañan unos títulos de la Editorial Calleja (Ruiz, 2002), realizados por Narciso Méndez Bringa (1868-1933) (Urdiales, 2008). Las construcciones visuales de Méndez Bringa aportan la claridad necesaria para construir mensajes inequívocos.

Como ya he indicado anteriormente, esas representaciones ofrecen escenas protagonizadas por una reprimenda o un reconocimiento. Las de reconocimiento se corresponden con las visitas a la escuela del inspector de enseñanza y de las autoridades de la localidad. En este caso las aulas se presentan al espectador dando prioridad a la comprensión (Fig. 13). Claridad para comprender el aula escolar que se caracteriza en la imagen por la linealidad de su suelo de tablas de madera, muy útil para construir la profundidad del espacio representado, pero también por los elementos que lo componen: la pizarra, los pupitres que albergan a los alumnos y el estrado en el que se coloca el profesor en el que se insinúa el crucifijo. La disposición de estos elementos persigue su identificación, aunque su disposición no posea demasiada lógica. ¿Cómo mirarán los alumnos a esa pizarra que está en un ángulo imposible de ver, ¿ por qué el estrado está ubicado perpendicularmente a los pupitres? En todos los casos el protagonismo reside en la exaltación de algún alumno que va a ser premiado o en la presencia de las autoridades. Destaca la actitud de los niños con su mirada dirigida hacia el suelo, apenas escudriñando lo que ocurre a su alrededor, en esa mezcla de candidez y sumisión, defendida por la mayor parte del sistema escolar de entonces. La determinación de la línea utilizada por Méndez Bringa en el dibujo original y por el grabado realizado por Samprieto contribuye a clarificar el discurso narrativo.

El tipo de aula al que me estoy refiriendo caracterizará la segunda mitad del siglo XIX e incluso los primeros años del siguiente en los que como han señalado Escolano y Viñao $(2006,47-71)$ se producen los primeros cambios.

Las escenas de castigo o reprimenda presentan un matiz muy llamativo. $\mathrm{Si}$ analizamos otras dos ilustraciones del mismo dibujante - Méndez Bringa- 


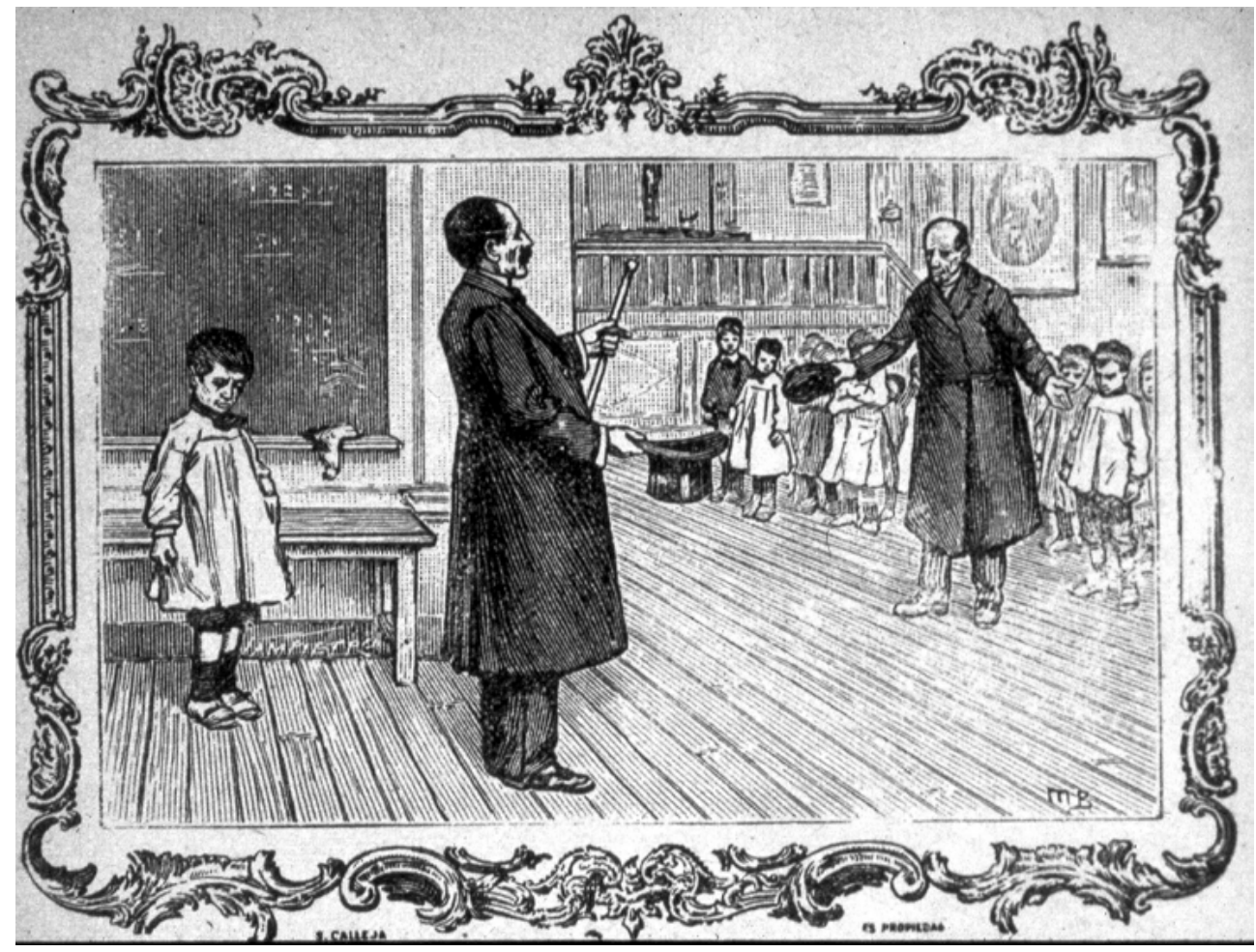

Fig. 13. Narciso Méndez Bringa. Los deberes de los niños. Madrid: Calleja.1915. 16 x 12 cm.

materializadas mediante grabados por Eugenio Vela, observamos grandes diferencias (Fig. 14). Para empezar, las figuras que centran la acción, el maestro y el alumno, se muestran en un tamaño mayor que en las anteriores. Bien es cierto que los formatos de las imágenes y del libro tienen distinta configuración, mucho menores y en la parte superior de la página en los primeros y a página completa en los segundos. Pese a ello, ese tamaño se conjuga con un punto de vista para el espectador mucho más próximo, están dibujadas para mostrar mayor cercanía con el observador, consiguiendo que la diferencia de altura entre el maestro y el alumno contribuya a conceder una impronta de respeto y temor, incluso físico.

Los elementos ambientales poseen también otro significado, el aula no está tan claramente descrita por la imagen. Sí caracterizada con las láminas, el reloj, el estrado (Costa, 2006.), pero sobre todo en la segunda la iluminación es un factor clave, la presencia de los grandes ventanales establece un leve contraluz en el que se recortan las figuras del maestro y el reprendido, así como el conjunto asustando de los alumnos que asisten a la reprimenda.

Los maestros de estas escenas no muestran apenas parecido con aquellos más jocosos que inundaban los textos ficticios para divertir al niño. Aquí visten de forma 


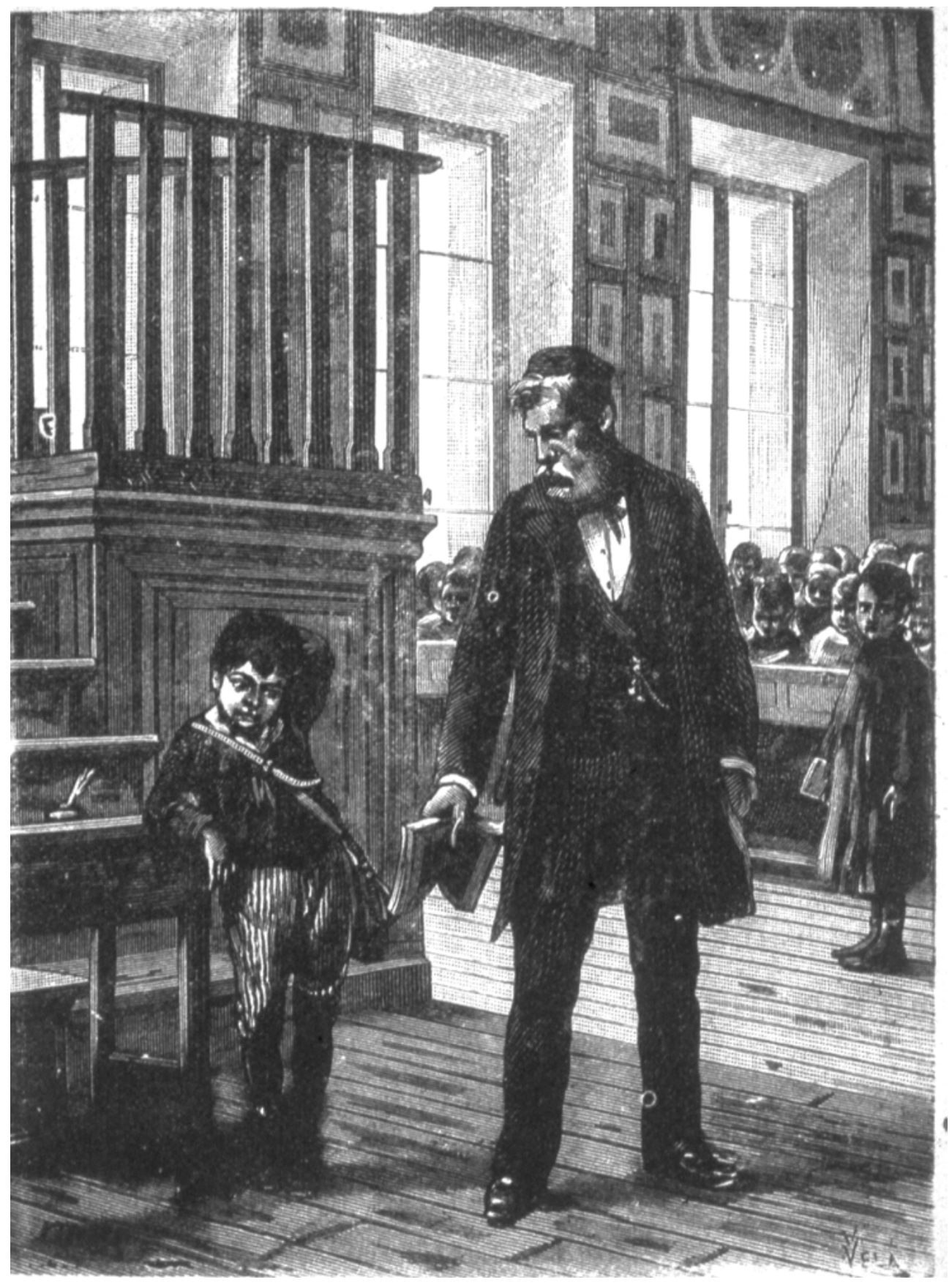

Fig. 14. Narciso Méndez Bringa. Los deberes de los niños. Madrid: Calleja. 1915. 16 x 12 cm. 
seria, utilizan levita o abrigo, bata en el caso de las maestras y solo en una de las imágenes reconocemos un bonete en la cabeza del maestro. Podría pensarse que estas imágenes están muy alejadas en el tiempo de las satíricas, pero no es así. Tampoco se debe pensar en el dominio único de este tipo de ilustraciones. En la prensa infantil del momento se pueden ver caracterizaciones del aula más dulces que las comentadas, como las que protagonizan las primeras páginas de la revista El Mundo de los Niños en sus números 2 y 16 de 1889. No obstante, su presencia en los libros de lectura de casas editoriales como Calleja, con tanta implantación en el ámbito escolar, les conceden una fuerte prevalencia.

La representación del aula y el maestro no desaparecerá de los libros infantiles en las tres primeras décadas del siglo xx en España. Podría decirse que existen grandes diferencias en la concepción de libros e imágenes entre 1876 y el final de la primera década del siglo xx y en el período inmediatamente posterior hasta 1931. Los textos de lectura con contenido moral, aquellos que pueden identificarse con el comportamiento del niño/a modelo y su buen desempeño, tan influido por la obra de escritores de orientación conservadora nacidos en la primera mitad del siglo XIX o incluso antes (Parravicini, Ducray-Duminil, Schmidt), seguirán siendo reeditados, pero cada vez serán menos omnipresentes. Decaerá pues, sin desaparecer, la representación del maestro inasequible al que temer. La escuela del castigo y el premio seguirá vigente, aunque convivirá con los nuevos métodos que recogerán las ideas de la Escuela Nueva. Esto se refleja en las fechas de edición y reedición. En la pertinaz presencia de representaciones de maestros tonantes, alojados a menudo en libros con cubiertas acordes con los nuevos tiempos. También en la adaptación de la imagen a la nueva realidad, no solo en el escenario de un aula más práctica (Escolano 2006, 33-38), sino en el lenguaje plástico empleado para ello. Así el niño modélico de los años veinte en un texto claramente conservador, se presentará con la claridad de la historieta propia del tebeo ante un profesor caracterizado de un modo mucho más actual (Fig. 15).

Al contrario, las imágenes satíricas que estaban presentes solo en el ámbito de los adultos aparecen en ese primer tercio del siglo Xx acompañando textos de diversión y entretenimiento, aunque a veces no dejen de estar atravesados por la vieja moral. Esto ocurre con los productos editoriales de Sopena que hemos analizado que pueden localizarse entre 1917 y 1930.

Las ilustraciones no son solo el reflejo de una ideología y de un contexto social y cultural, tendrán una génesis formal y constructiva y unos recursos orientados a un tipo determinado de percepción que el dibujante elaborará. Las tradiciones representativas, las ilustraciones que actúan como modelo, que incluso algunos ilustradores plagian, tiene un papel determinante en el resultado final de la imagen en la retina y sus análisis no puede desestimarse de la revisión que hoy se lleva a cabo de los productos editoriales para los niños en el pasado. 
EN EL COLEGIO, - EL NIÑO BIEN EDUCADO

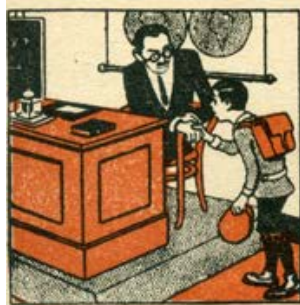

FL entrar en clase saluda respetuosamente al sefior profesor.

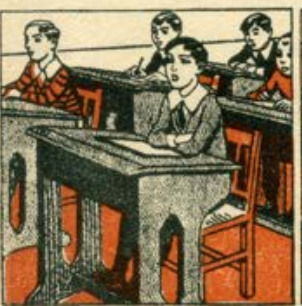

SuARDA atención y buena compostura para no estorbar ni distraer a los compañeros.

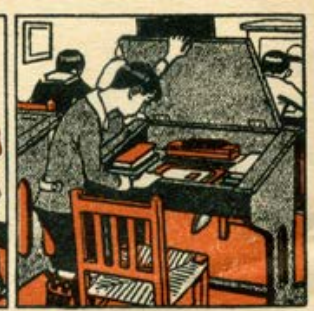

$Z_{S}$ un gusto ver su pupitre siempre muy limpio y arreglado con mucho orden.

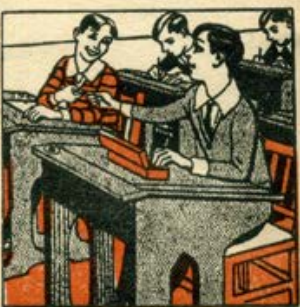

¿s servicial siempre que puede y que lo permite el reglamento del colegio. $A *$

\section{EN EL COLEGIO.-EL NINOO MAL EDUCADO}

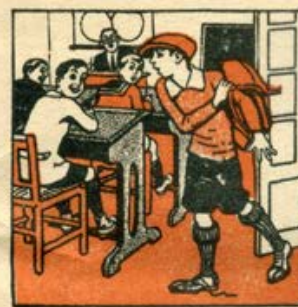

LLEGA siempre atrasado porque no sale a tiempo de cese.

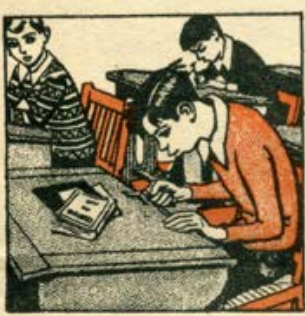

DA muestras de instintos perversos destrozando las mesas y manchándolas.

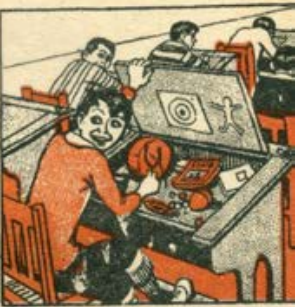

SU pupitre es una leonera; tiene en él muchas cosas que no debiera tener.

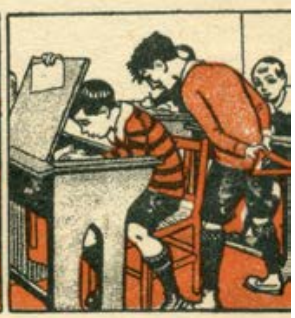

SASTA bromas pesadas, por gusto de molestar a sus. companteros.

Fig. 15. Anónimo. Cartilla moderna de Urbanidad. Barcelona: FTD. 1929. 15,5 x $11 \mathrm{~cm}$.

\section{CONCLUSIONES}

La representación del maestro ha jugado un papel importante en los sistemas educativos del pasado. La referencia visual del educador se identificó a menudo con el propio sistema personalizándolo en un hombre o una mujer. Curiosamente, un importante número de imágenes protagonizadas por maestros estuvieron destinadas a los adultos, conformando la mayor parte de las escenas de costumbres en las que la realidad se mostraba, a menudo, desde el prisma de la comicidad. Incorporadas al acervo popular desde el siglo XVI su pervivencia es evidente en el siglo XIX, momento en el que la presencia de publicaciones e imágenes para niños se incrementa de forma notable.

Una parte destacada del icono, del arquetipo visual del maestro, se estableció con la condición miserable que acompañó al desempeño de su trabajo y con las situaciones escolares en las que los alumnos rompían con el orden escolar. Esa representación de un individuo torpe, a menudo vengativo y vestido pobremente, saltó a las publicaciones satíricas para denunciar tanto su situación como la de la escuela y la instrucción pública. En los textos infantiles de entretenimiento su presencia buscará divertir a los niños, dejando tan claro como puede hacerlo una metáfora en la 
edad infantil, que esa escuela y ese maestro solo residían en un mundo dominado por la fantasía.

El tipo, identificado en España con el del dómine, adquiere una apariencia muy diferente en los textos dedicados a enseñar adoctrinando a los alumnos. En estas escenas la claridad de la línea y la imagen o la escenografía reforzarán los mensajes.

En todos los casos el análisis de las ilustraciones de contenido escolar no puede obviar la autoría artística de quienes las originaron. Los caricaturistas e ilustradores emplearán modelos procedentes de su entorno artístico. En este sentido en la configuración de ese maestro con gorro de dormir, bata o gabán, pobremente calzado, jugarán un papel importante las representaciones provenientes de Gran Bretaña que recogían, a su vez, la tradición de los Países Bajos. Esta imagen asumirá en la España de la Restauración un ácido realismo y el aspecto del viejo dómine dieciochesco.

Tampoco es desdeñable el papel que juegan en estas ilustraciones el modo en el que se construyen, el empleo de la línea que las compone, la organización del espacio en el que se encuentran, la utilización del punto de vista del supuesto espectador, la representación de la luz y el juego que establecen con las figuras. Estos aspectos, menos considerados en los análisis al uso, en los que predominan los ideológicos centrándose en los editores y en los textos que acompañan las ilustraciones, son claves para comprender su funcionamiento.

Una imagen no puede aislarse de su contexto visual, en él confluyen los horizontes visuales de los espectadores y la configuración personal de los creadores. Ciertamente, esos universos están al servicio de un producto editorial. Sabemos cómo se trabajaba entonces siendo a menudo los textos los que comenzaban el proceso. Los textos, su orientación y el de quienes los encargaban o seleccionaban, son fundamentales para entender el resultado final. No obstante, y con la aprobación del editor, es el dibujante, y el grabador, quienes darán forma a la ilustración. En ese sentido el origen iconográfico de algunas de las figuras, de su indumentaria y aspecto, es importante para entender su presencia en ese itinerario cultural que compone la vida de las imágenes. La manera de ordenar los elementos que establecen la escena visual, los escenarios y lugares, su caracterización, las actitudes de las figuras, su indumentaria, la luz que las orienta o determina, el punto de vista elegido para su contemplación.

El maestro y la escuela muestran modos diferentes de presentarse. Lo hacen en función de los intereses sociales de cada momento, pero también de las demandas, gustos y recursos técnicos que permiten componer la representación. En aquellos que hemos analizado se pueden observar continuidades iconográficas e ideológicas, pero también innovaciones y cambios. O lo que es más curioso continuidades presentadas con recursos novedosos, adecuados al gusto y uso del observador. 


\section{REFERENCIAS BIBLIOGRÁFICAS}

Alpers, S. (1987). El arte de describir. El arte holandés en el siglo XVII. Madrid: Hermann Blume.

Armangué, J. (2007). L'obra primerenca de Apel-les Mestres. Del Romanticisme al Naturalisme. Barcelona: Publicacións de L'Abadia de Montserrat.

Bove, F. (2018). Nurturing genius in a pigsty: George Morland and the making of the modern artist. (Tesis doctoral inedita). University of East Anglia. Norwich https://ueaeprints.uea.ac.uk/id/eprint/69194/

Bozal, V. (1978). La ilustración gráfica del XIX en España. Madrid: Comunicación.

Bozal, V. (1980). Los españoles pintados por sí mismos y la llustración Romántica. Boletín del Museo e Instituto Camón Aznar, 1, pp. 58-81.

Bozal, V. (1989). El siglo de los caricaturistas. Madrid: Historia 16.

Briongos, H. (2015). El problema salarial de los maestros de primera enseñanza en los debates parlamentarios del congreso de los diputados (1900 a 1923). (Tesis doctoral inédita). Universidad de Burgos. Burgos. https://riubu.ubu.es/ handle/10259/4458

Bullard, P. (Ed.). (2019). The Oxford Handbook of Eighteenth-Century Satire. Oxford: University of Oxford. https://doi.org/10.1093/ oxfordhb/9780198727835.001.0001

Burke, P. (2007). La historial cultural y sus vecinos. Alteridades, 17(33), pp. 111-117. http://www.scielo.org.mx/scielo.php?script=sci_arttext\&pid $=$ S0188-70172007000100011

Casado, P. (2006). Diccionario biográfico de ilustradores del siglo xIX. Madrid: Ollero y Ramos.

Castellani, J. P., Zapata, M. (Eds.) (2007). Texte e Image dans les Mondes Hispaniques et Hispano-Américains. Tours: Presses Universitaires François-Rabelais. https:// doi.org/10.4000/books.pufr.6280 
Chateau, P. (2017). Cultura visual e Historia del Arte. La puesta en evidencia de los Estudios Visuales. UNIVERSUM, 32(2), pp. 15-28. https://doi.org/10.4067/ S0718-23762017000200015

Costa, A. (2006). El ajuar de la escuela. En A. Escolano (dir.), Historia ilustrada de la escuela en España (pp. 197-218). Madrid: Fundación Germán. Sánchez Rupérez.

De Blas, J. (1994). Bibliografía del arte gráfico grabado, litografía, serigrafía: historia, técnicas, artistas. Madrid: Calcografía Nacional.

Doizy, G. (2007). Les Corbeaux contre la calotte. La lutte anticléricale par l'image à la Belle Époque. St-Georges-d’Oléron: Editions Libertaires.

Escolano A. (2006) La cultura de la escuela en el sistema educativo liberal. En A. Escolano (dir.), Historia ilustrada de la escuela en España (pp. 23-46). Madrid: Fundación Germán. Sánchez Rupérez.

Escolano A. (2006) La codificación de la primera manualística. En A. Escolano (dir.), Historia ilustrada de la escuela en España (pp. 219-239). Madrid: Fundación Germán. Sánchez Rupérez.

García, J. (2004). Formas y colores: la ilustración infantil en España. Cuenca: Universidad de Castilla- La Mancha.

Gil-Díez, I. (1987). Bestias pardas. La balsa de la Medusa, 3, pp. 41-52. https:// classic.europeana.eu/portal/es/record/2022702/oai_prensahistorica_mcu_ es_1028766.html?q=Bestias+pardas\#dcld=1609862114558\&p=1

Huidobro, C. (coord.) (2012). Durero grabador. Del Gótico al Renacimiento. Obras de la Biblioteca Nacional de España. Santa Cruz de Tenerife: Obra social Caja Canarias.

Fuentes Arboix, M. (2014). La sátira política en la primera mitad del siglo XIX. Fray Gerundio (1837-1842). (Tesis doctoral inédita). Universidad de Alicante. Alicante. http://uvadoc.uva.es/handle/10324/21538

Guereña, J. L. (2005). El alfabeto de las buenas maneras. Los manuales de urbanidad en la España contemporánea. Madrid: Fundación Germán Sánchez Rupérez. https://doi.org/10.4000/books.pufr.5655 
Guereña, J. L. (Ed.) (2007). Image et Transmission des Savoirs dans les Mondes Hispaniques et Hispano-Américains. Tours: Presses Universitaires FrançoisRabelais.

Martín, A. (1978). Historia del comic español: 1875-1939. Barcelona: Gustavo Gili.

Mount, H. T. (1991). The reception of Dutch genre painting in England 1695-1829. (Tesis doctoral inedita). University of Cambridge. Cambridge. https://doi. org/10.17863/CAM.15878

Nóvoa, A. (2000). Ways of saying, ways of seeing public images of teachers $\left(19^{\text {th }}\right.$ $20^{\text {th }}$ Centuries). Paedagogica Historica: International Journal of the history of education, 36(1), pp. 21-52. https://doi.org/10.1080/0030923000360102

Orenstein, N. (Ed.). (2001). Pieter Bruegel the Elder: Drawings and Prints. New York: Metropolitan Museum.

Pozo, M. M. del. (2006). Imágenes e historia de la educación: construcción, reconstrucción y representación de las prácticas escolares en el aula. Historia de la Educación, 25, pp. 291-315. https://revistas.usal.es/index.php/02120267/article/view/11183

Pozo, M. M. del, Braster, S. (2017). Exploring New Ways of Studying School Memories: The Engraving as a Blind Spot of the History of Education. En C. Yanes Cabrera et al. (Eds.). School Memories (pp. 11-27). Cham: Springer. https://doi.org/10.1007/978-3-319-44063-7

Rivalan-Guégo, C. (2013). Ramón Sopena, éditeur à la page (Barcelone, début du XXe siècle). Langues néo-latines: Revue des langues vivantes romanes, 364, pp. 77-94.

Ruiz, J. (Dir.). (2002). La editorial Calleja, un agente de modernización educativa en la Restauración. Madrid: UNED.

Soler, X. (2004). El dibuix a Catalunya. 100 dibuixants que cal coneixer. Barcelona: Associació Conèixer Catalunya.

Urdiales, A. (2008). El mejor realista para los niños, Narciso Méndez Bringa (18681933). Educación y biblioteca, 166, pp.18-21. https://gredos.usal.es/bitstream/ handle/10366/119544/EB20_N166_P18-21.pdf?sequence=1\&isAllowed=y 
VV. AA. (2008). Honoré Daumier. Madrid: Fundación Banco de Santander.

Viñao, A. (2006). Templos de la patria, templos del saber. Los espacios de la escuela y la arquitectura escolar. En A. Escolano (dir.) Historia ilustrada de la escuela en España (pp. 47-72). Madrid: Fundación Germán Sánchez Rupérez. 